Darko DIMOVSKI, vanredni profesor ${ }^{*}$ Pravni fakultet, Univerzitet u Nišu
Originalni naučni rad

UDK: $343.6: 177.82(=411.16)(410)$

$342.724(=411.16)(410)$

Primljeno:6.2.2020.

Prihvaćeno:1.3.2020.

https://doi.org/10.47152/rkkp.58.1.2.2

\title{
JEVREJI KAO ŽRTVE ZLOČINA MRŽNJE U VELIKOJ BRITANIJI**
}

O predrasudama, koje postoje prema pripadnicima jevrejskog naroda, moguće je navesti mnogo primera tokom istorije. Autor je stoga u uvodnom delu rada naveo nekolicinu primera kako bi ilustrovao negativan odnos većinskog stanovništva prema ovoj etničkoj zajednici. Koristeći kao razlog da je jevrejska zajednica među najbrojnijima u svetu u Velikoj Britaniji, autor je u daljem radu obrazložio po godinama obim i strukturu zločina mržnje prema Jevrejima, trudeći se da da objašnjenje dinamike izvršenih zločina mržnje. Na kraju rada ukazuje na zaključke koji bi se mogli primeniti radi smanjena viktimizacije pripadnika jevrejske zajednice.

Ključne reči: zločin mržnje, Jevreji, Velika Britanija, žrtve.

* e-mail: darko@prafak.ni.ac.rs

** Ovaj rad predstavlja rezultat teorijskog istraživanja na projektu „Usklađivanje prava Srbije sa pravom EU“, koji se sprovodi na Pravnom fakultetu Univerziteta u Nišu. 


\section{Uvod}

O negativnom odnosu prema Jevrejima svedoči podatak da su svi Jevreji proterani iz Engleske 1290 godine. To isto im se dogodilo i 1306. godine kada su proterani iz Francuske. Razlog tome treba tražiti u činjenici da su se u srednjovekovnoj Evropi razvile predrasude i glasine o jevrejskom narodu. Jedna od glasina, koja je umnogome odredila odnos engleskog naroda prema Jevrejima, je vezana za događaj iz 1114. godine u Norviču (Norwich). Naime, tada je nestalo dete po imenu Vilijam (William) koje je ubrzo pronađeno mrtvo. Hrišćanski monah Teobald (Theobald) je ubrzo počeo da širi glasine da su za ubistvo krivi Jevreji koji su Vilijama žrtvovali kako bi dobili krv za svoje verske obrede. Fanatični sveštenici su uspeli da ovaj nerasvetljeni događaj iskoriste kako bi indoktrinirali svoje vernike protiv jevrejskog naroda, bez obzira na to što judaizam strogo zabranjuje bilo kakvo ritualno ubistvo (Rawcliffe, Wilson, 2006:42).

Još jedna predrasude prema Jevrejima stvorena je 1215. godine kada je Katolička crkva objavila dogmu transubstancije koja znači da sveti hleb i sveto vino konzumirani od strane hrišćana predstavljaju telo i krv Isusa Hrista. Naime, ubrzo je proširena glasina da Jevreji kradu sveti hleb i probadaju ga iglama, što se povezuje sa ponovnim razapinjanjem Isusa. Iako je širenje ovakve glasine bilo neozbiljno, ona je dovela do masakra velikog broja Jevreja. Tako je, na primer, poznati mrzilac Jevreja Rindflajš (Rindfleisch) 1298. godine proširio ovu glasinu u srednjovekovnoj Nemačkoj i Austriji, što je imalo za rezultat uništenje preko 150 jevrejskih zajednica i smrt preko 100.000 ljudi (Rawcliffe, Wilson, 2006:42).

Drugi svetski rat, za koji pojedini istoričari smatraju da, usled istih razloga za njegovo vođenje i usled strana u sukobu, predstavlja nastavak Prvog svetskog rata, doveo je do velikog stradanja pripadnika jevrejskog naroda u Evropi. Za razliku od Prvog svetskog rata u kojem je bilo oko pola miliona Jevreja koji su se borili na obema stranama u sukobu, u Drugom svetskom ratu Jevreji su bili žrtve sistematskog uništenja predvođeni nacističkom Nemačkom. Najveći zločin mržnje prema Jevrejima počinjen za vreme Drugog svetskog rata kada je od strane nacističke Nemačke lišeno života preko 6 miliona osoba jevrejskog porekla, što je značilo da je dve trećine od ukupne jevrejske populacije u Evropi bilo ubijeno, što u gasnim komorama, što od loših uslova u koncetracionim kampovima i getoima, što od strane Einsatzgruppen u istočnoevropskim zemljama.

Predrasude, koje su bile u osnovi vršenja svih zločina prema Jevrejima kroz istoriju, postoje i danas. Takve predrasude postoje u državama širom sveta. Međutim, kako je nemoguće predstaviti stepen viktimizacije Jevreja u državama širom sveta, fokusiraćemo se samo na viktimizacije pripadnije jevrejske popula- 
cije u Velikoj Britaniji, jer prema podacima iz 2011. godine broj Jevreja u Velikoj Britaniji iznosi 269.568 građana od ukupno nešto više od 56 miliona. To ih stavlja na petu poziciju po brojnosti u ovoj državi, a na drugu poziciju po stepenu brojnosti u državama Evrope posle Francuske. ${ }^{1}$

\section{Zločini mržnje prema Jevrejima u Velikoj Britaniji}

Velika Britanija kao multikulturalna zemlja ima dosta problema sa zločinima mržnje usmerenim prema jevrejskoj populaciji. Ipak, i dalje ne postoji vladino telo nadležno za prikupljanje podataka o izvršenim krivičnim delima prema Jevrejima usled postojanja predrasude, nakon čega bi se ti podaci publikovali. Međutim, nevladina organizacija pod nazivom Community Security Trust, osnovana 1994. godine s ciljem obezbeđivanja sigurnosti jevrejskoj populaciji u Velikoj Britaniji, na jedan sistematičan način prikuplja podatke o zločinima mržnje tako što intervjuiše žrtve, analizira novinske i policijske izveštaje. Stoga je moguće pratiti trend izvršenih zločina mržnje prema jevrejskoj populaciji (Perry, 2009:109). Pre nego što krenemo na obrazlaganje stope i strukture izvršenih zločina mržnje prema Jevrejima, treba napomenuti da ćemo se zbog ograničenja u pogledu duženi članka fokusirati samo na dve kategorije zločina mržnje izvršenih prema Jevrejima - nasilni zločini mržnje (napadi) i uništenje i oštećenje imovine.

$\mathrm{Na}$ broj izvršenih zločina mržnje prema ovog etničkoj i religijskoj grupi mogu uticati događaji koji nisu prostorno vezani za Veliku Britaniju. Tako su, na primer, na povećan broj izvršenih zločina mržnje tokom 2001. godine uticala dva razloga. Prvi razlog se ogleda u započinjanju drugog ustanka, tzv. Intifada (Intifadah) Palestinaca protiv jevrejske okupacije u oblasti Gaze i Zapadne Obale 2000. godine, dok se drugi razlog otelotvoruje u napadu muslimanskih terorista pod okriljem Al Kaide 11. septembra 2001. godine na Sjedinjene Američke Države, što je rezultiralo povećanjem neprijateljskih aktivnosti prema jevrejskom narodu širom sveta, pa i u Velikoj Britaniji. ${ }^{2}$

Ujedno, moguće je analizirati broj izvršenih zločina mržnje prema Jevrejima u Velikoj Britaniji iz godine u godinu. Community Security Trust je publikovao izveštaj o zločinima mržnje prema jevrejskoj populaciji za 2010. godinu, pri čemu je naglašeno da je sa cifrom od 639 zabeleženih antisemitskih incidenata, 2010. godina druga godina sa najvećim brojem izvršenih zločina mržnje

1 https://www.worldjewishcongress.org/en/about/communities/GB $\% 20 \% \mathrm{C} 2 \% \mathrm{~A} 0$, stranici pristupljeno 22. januara 2020. godine.

2 http://www.jewishvirtuallibrary.org/global-anti-semitic-trends-report-2001, stranici pristupljeno 12. marta 2018. godine. 
od 1984. godine. Ipak, u odnosu na 2009. godinu izvršeno je za $31 \%$ manje krivičnih dela koja se mogu podvesti pod zločin mržnje prema Jevrejima. Međutim, bez obzira na drastičan pad u odnosu na 2009. godinu, treba naglasiti da brojka od 639 zabeleženih incidenata sa elementima antisemitizma predstavlja za $17 \%$ više u poređenju sa 2008. godinom kada je bilo 546 takvih incidenata, što nam ukazuje na postojanje trenda povećanja broja izvršenih zločina mržnje i veće ugroženosti jevrejske populacije. Takođe, treba napomenuti da je tokom 2010. godine došlo do novog sukoba zbog dešavanja u Gazi. Naime, propalestinski aktivisti, koji su plovili na brodu pod turskom zastavom, pokušali su da probiju morsku blokadu Gaze, pri čemu je došlo do sukoba sa izraelskom vojskom i ubistvom devet aktivista. Ovo je nesumnjivo dovelo po povećanja broja antisemitskih incidenata u Velikoj Britaniji, jer je, na primer, tokom juna 2010. godine izvršeno 81 antisemitski incident, dok je juna prethodne godina ta brojka iznosila 49 uz nepostojanje sličnog događaja u tom periodu (Antisemitic Incidents Report, 2010:4).

Ujedno, tokom 2010. godine izvršeno je 114 napada na jevrejsku populaciju u Velikoj Britaniji, što je pad od osam procenata u odnosu na prethodnu godinu kada je zabeleženo 124 napada. U 75 slučajeva žrtve napada su bile osobe muškog pola, dok u 48 slučajeva su bila punoletna lica. Maloletnici su bili žrtve kod 25 zločina mržnje sa elementima nasilja. Do napada na Jevreje od strane pripadnika različitih rasa, kao što su belci, ali i Azijati, je dolazilo dok su oni mirno šetali ulicom. Treba spomenuti slučaj iz decembra 2010. godine, kada je jedan Jevrejin, vozeći auto kroz centar Londona, na svom radiju pustio glasno izraelsku muziku. Iritiran time, automobilu je prišao Arapin i udario njegov auto. Nakon toga je Jevrejin izašao iz automobila, ali je dobio batine od grupe Arapa i azilanata, pri čemu je zadobio povrede glave (Antisemitic Incidents Report, 2010:13).

Jevrejska populacija u Velikoj Britaniji izložena je napadima na njihovu imovinu. Za razliku od 2009. godine kada je zabeleženo 89 zločina mržnje uperenim prema imovini, tokom 2010. godine broj ovih krivičnih dela pao je za sedam procenata i iznosio je 83 krivična dela. Od ukupnog broja krivičnih dela protiv imovine, njih 15 se odnosilo na skrnavljenje sinagoga, dok se jedno krivično delo odnosi na uništenje jevrejskog groblja. Uništivanje sinagoga i groblje je vršeno na taj način da su na njima iscrtavani svastike i grafiti sa porukama mržnje poput "jevrejska ološ", "Hezbolah dolazi" i tako dalje (Antisemitic Incidents Report, 2010:14).

Godina 2011. sa ukupnim brojem od 586 antisemitskih incidenata predstavlja drugu godinu zaredom u kojoj se beleži trend pada izvršenih krivičnih dela prema jevrejskoj populaciji. U odnosu na prethodnu godinu,kada je zabeleženo 645 incidenata, broj od 586 incidenata je smanjenje za $9 \%$. U poređenju sa 
još nekim godinama, kada je broj izvršenih zločina mržnje bio veliki, dolazimo do zaključka da se 2011. godina nalazi na četvrtom mestu po broju ukupno izvršenih krivičnih dela prema jevrejskoj populaciji, ali i da ima najniži broj zločina mržnje od 2008. godine kada je zabeleženo 546 antisemitskih incidenata. Razlog pada broja registrovanih antisemitskih incidenata treba tražiti u nepostojanju nekog događaja koji bi predstavljao okidač nasilnicima da svoje predrasude i frustraciju usmere ka pripadnicima jevrejske populacije. Ukoliko proučavamo broj izvršenih zločina mržnje prema mesecima tokom 2011. godine, uvidećemo da je septembar sa 72 antisemitska incidenta najviše zastupljen. Objašnjenje se ogleda u tome da su tokom septembra Jevreji naročito uočljivi drugim građanima zbog proslave jevrejske Nove godine. Tako je tokom tri dana proslave Noive godine bilo zabeleženo 18 zločina mržnje (Antisemitic Incidents Report, 2011:4).

Kako je tokom 2010. godine bilo registrovano 114 nasilnih zločina mržnje prema Jevrejima, a godinu dana kasnije 92 takvih dela, vidimo da je zabeležen pad od 19\%, što je najmanja brojka nasilnih zločina mržnje prema ovoj populaciji još od 2008. godine kada je zabeleženo svega 88 ovakvih napada (Antisemitic Incidents Report, 2011:12-13). Dublja analiza izvršenih zločina mržnje sa elementima nasilja dovodi nas do zaključka da su 79 od ukupno 92 nasilnih zločina mržnje izvršena na javnim mestima, bez nekog unapred pripremljenog plana napada, što nam ukazuje da su napadi bili oportunistički. Od ukupnog broja napada 56 je bilo usmereno prema osobama koje su, zbog načina odevanja, očigledno bili jevrejskog porekla. Devet napada se dogodilo tokom povratka Jevreja sa molitve iz sinagoga. Kod 51 napada žrtve su bile osobe muškog pola. Naročito je vredan pomena napad na jevrejsku porodicu dok je stala na benzijskoj pumpi da natoči gorivo. Do napada je došlo dok je jedan član porodice išao do pumpinog objekta kako bi platio gorivo. Ona je udarena drugim automobilom u kojem su bili dvojica belaca. Nakon toga dvojica napadača su izašla iz auta, udarajući žrtvu i vičući "prljavi Jevreji". Naredni napad vredan pomena desio se na autobuskoj stanici. Naime, tom prilikom napadnuta je jevrejska devojčica od strane tri starije maloletnice tako što su joj one udarile šamare. Jula 2011. godine u Londonu je došlo do novog napada. Jevrejin, hodajući ulicom, bio je izložen napadu od strane grupe belaca uz nanošenje telesnih povreda. Grad Salford (Salford) je bio poprište narednog zločina mržnje sa elementima nasilja. Do napada je došlo tako što se par belaca zaustavio, pri čemu je muškarac izašao iz automobila i oborio sa glave tzv. jarmulku (tradicionalnu jevrejsku kapu), uz nanošenje Jevrejinu lakših telesnih povreda (Antisemitic Incidents Report, 2011:13).

Takođe, brojna krivična dela protiv Jevreja su za objekat napada imala njihovu imovinu. Tako je tokom 2011. godine bilo registrovano 63 krivičnih dela protiv imovine pripadnika jevrejske populacije. To predstavlja pad od $24 \%$ u od- 
nosu na prethodnu godinu, kada je bilo izvršeno 83 krivična dela protiv imovine u vlasništvu Jevreja. Ujedno, broj od 63 ovih krivičnih dela je najmanji od 2005. godine kada je zabeleženo svega 48 zločina mržnje protiv imovine. Četrnaest sinagoga je oskrnavljeno, kao i 4 jevrejska groblja. Oštećeni ili uništeni su 26 domova ili automobila parkiranih ispred jevrejskih kuća. Krivična dela protiv imovine Jevreja ogledala su se u ispisivanju grafita "Jebeš Jevreje" na vratima sinagoge, ili crtanja sinagoge na ulaznim vratima (Antisemitic Incidents Report, 2011:15).

Praksa publikovanja izveštaja o zločinima mržnje prema jevrejskoj populaciji u Velikoj Britaniji od strane Community Security Trust nastavljena je tokom 2012. godine. Sa brojem od 640 zabeleženih antisemitskih incidenata za 2012. godinu vidimo da je došlo do povećanja od pet procenata u odnosu na 2011. godinu. Kao i kod pojedinih prethodnih godina, i kod 2012. godine imamo trend porasta broja izvršenih zločina mržnje kao reakciju na spoljna dešavanja. Naime, marta 2012. godine izvršeno je 75 zločina mržnje, dok je novembra iste godine taj broj bio još veći i iznosio je 82 zločina mržnje. Spoljna dešavanja, koja su imala uticaj na povećanje broja izvršenih zločina mržnje tokom marta i novembra, su teroristički napad na jevrejsku školu u Tuluzu (Toulouse) u Francuskoj u martu i eskalacije konflikta u južnom delu Izraela i Gazi u novembru. Ipak, neki kriminolozi tvrde da je povećanje broja zabeleženih zločina mržnje tokom marta posledica povećanje aktivnosti jevrejskih nevladinih organizacija tokom marta, a ne posledica dešavanja u Tuluzu. Ujedno, treba napomenuti da je značaj društvenih mreža porastao, te da su mogućnosti za njihovu zloupotrebu zarad izvršenja zločina mržnje porasle. Naime, za razliku od 2011. godine kada je zabeleženo svega 12 krivičnih dela protiv Jevreja upotrebom društvenih mreža, tokom 2012. godine ta brojka se popela na 80 (Antisemitic Incidents Report, 2012:3).

Broj nasilnih zločina mržnje prema Jevrejima tokom 2012. godine iznosio je 69 , što je drastičan pad u odnosu na prethodnu godinu kada je bilo zabeleženo 92 nasilna incidenta, što čini pad od 27\%. Godina 2012. predstavlja treću godinu zaredom u kojoj dolazi do pada broja nasilnih zločina mržnje prema jevrejskoj populaciji, te čini godinu sa najmanjim brojem takvih krivičnih dela od 2003. godine kada je zabeleženo svega 54 napada (Antisemitic Incidents Report, 2012:4).

Ukoliko analiziramo udeo nasilnih zločina mržnje u odnosu na sve antisemitske incidente uvidećemo da je u odnosu na 2011. godinu kada je udeo iznosio 16\%, tokom 2012. godine došlo je do pada udela zločina mržnje sa elementima nasilja na 11\%. Objašenjenje za novi pad udela nasilnih krivičnih dela treba tražiti u spremnosti žrtava jevrejskog porekla da prijavljuju manje društveno opasna krivična dela, kao i u javljanju novih mogućnosti vršenja zločina mržnje putem interneta i društvenih mreža. Od 69 nasilnih zločina mržnje, njih 56 su situaciona krivična dela koja su izvršena na javnim mestima, pri čemu su kod 
31 napada žrtve očigledno bile pripadnici jevrejske populacije. U deset slučajeva napadani su Jevreji prilikom dolaska ili odlaska iz sinagoge. Kod 37 napada prijavljene su i godine starosti žrtava, te znamo da su kod 20 napada žrtve bile odrasli pripadnici jevrejske zajednice, kod 15 napada su žrtve bili maloletnici, a kod 2 incidenta žrtve su bile zajedno punoletna i maloletna lica (Antisemitic Incidents Report, 2012:12).

Ujedno, zarad sticanja prave slike o stepenu viktimiziranosti Jevreja u Velikoj Britaniji navešćemo nekoliko slučajeva za koje smatramo da su vredni pažnje. Tako je jevrejski dečak tokom marta 2012. godine u Severnoj Irskoj bio žrtva nasilja u školi nakon časa na kojem se učilo o Holokaustu. Posledice napada su bile ozbiljne s obzirom da je dečak pretrpeo teške povrede. Do narednog napada sa ozbiljnim posledicama došlo je u Glazgovu u maju iste godine. Naime, napad se dogodio na uilici kada je Azijat fizički nasrnuo na par Jevreja, što je rezultiralo potrebom za njihovo zadržavanje u bolnici. Tom prilikom napadač je izvadio nož i zario ga u slučajnog prolaznika, vičući na njega "Da li si ti Jevrejin?" (Antisemitic Incidents Report, 2012:3).

Takođe, dešavali su se i drugi napadi na pripadnike jevrejske populacije, s tim da su posledice izvršenja datih krivičnih dela bile manje. Jedan od napada dogodio se u Londonu, kada su četvorica momaka prišla Jevrejinu, koji je nosio jarmulku, pri čemu ga je jedan od momaka udario nekoliko puta u lice, nanevši mu malu posekotinu iznad oka (Antisemitic Incidents Report, 2012:13).

Kao i kod krivičnih dela sa elementima nasilja, kod krivičnih dela protiv imovine u vlasništvu Jevreja je tokom 2012. godine zabeležen pad od 17\% u odnosu na prethodnu godinu. Naime, dok je 2011. godine bilo ukupno 64 zločina mržnje protiv imovine, tokom 2012. godine zabeleženo su 53 incidenta. Dobijeni rezultati su pokazali da broj zločina mržnje protiv imovine treću godinu zaredom pada. Tokom 2012. godine došlo je do skrnavljenja ili oštećenja devet sinagoga, kao i tri jevrejska groblja. Ujedno, izvršioci zločina mržnje za objekat napada su u 17 slučajeva imali jevrejske domove ili automobile u njihovom vlasništvu. Oštećenje imovine u vlasništvu Jevreja uglavnom se sastojala u crtanju svastike. Tako su zabeleženi slučajevi crtanja svastike u Lidsu (Leeds), Londonu, Merzisajdu (Merseyside), Lankaširu (Lancashire) itd. Interesantno je spomenuti slučaj koji se dogodio tokom marta 2012. godine u Londonu. Naime, belac je primećen kako kasno tokom noći udara u vrata sinagoge. Kako niko nije otvorio, vratio se sa slaninom koju je razbacao ispred ulaznih vrata. Ubrzo je uhapšen, te identifikovan od strane policije. Priznao je izvršenje krivičnog dela, pri čemu je dao dosta bizarno objašnjenje. Kako njegov televizor nije radio, on je bio ubeđen da je to zbog dešavanja u sinagogi, jer se u njoj nalazi telekomunikaciona opre- 
ma u vlasništvu izraelske obaveštajne agencije Mosad (Mossad) (Antisemitic Incidents Report, 2012:14).

Naredne godine zabaleženo su 529 antisemitskih incidenata, što predstavlja pad od 18\% u odnosu na 2012. godinu, kada je zabeleženo 649 takvih incidenata. Za razliku od 2012. godine, tokom 2013. godine nisu postojali nikakvi događaji u inostranstvu ili na teritoriji Velike Britanije koji bi doveli do povećanja broja zločina mržnje prema jevrejskoj populaciji. Ujedno, brojka od 529 incidenata za 2013. godinu čini datu godinu sa najmanjom stopom antisemitskih incidenata još od 2005. godine (Antisemitic Incidents Report, 2013:3).

Sa zabeleženim brojem od 69 nasilnih zločina mržnje prema jevrejskoj populaciji, 2013. godina je, kao i 2012. godina, sa najmanjim brojem ovakvih krivičnih dela od 2003. godine kada su registrovana 54 napada. Od ukupnog broja nasilnih zločina mržnje, njih 58 su situaciona krivična dela koja su izvršavana na javnim mestima. Kod devet zločina mržnje sa elementima nasilja objekat napada su bili Jevreji koji su se vraćali sa molitve iz sinagoga. Community Security Trust je zabeležio kod 49 napada pol žrtava. Naime, kod 38 napada su žrtve bili osobe muškog pola, dok su osobe ženskog pola bile žrtve napada samo kod tri zločina mržnje. Parovi, kao i grupe sastavljene od oba pola, bile su žrtve napada kod osam zločina mržnje. Ujedno, pomenuta nevladina organizacija je za 27 napada imala podatke o godinama starosti žrtava. Tako su kod 13 napada žrtve bila punoletna lica, kod 9 napada su bili maloletnici, a kod 5 napada žrtve su bile grupe u kojima su bila punoletna i maloletna lica (Antisemitic Incidents Report, 2013:12).

Grad po imenu Gejtshed (Gateshead) bio je u januaru 2013. godine poprište napada na tri Jevrejke od strane grupe mladih sastavljenih od osoba ženskog i muškog pola. Tom prilikom su napadači uzvikivali antisemitske parole. Februara se dogodio novi napad na jevrejsku populaciju u Mančesteru. Tada je pijani muškarac, oko pedeset godina starosti, vikao i vređao Jevrejina, pre nego što ga je udario u lice. Odmah nakon toga napao je još tri pripadnika jevrejske populacije. Ubrzo je uhapšen i osuđen na uslovnu kaznu zatvora, uz izricanje novčane kazne od 80 funti (Antisemitic Incidents Report, 2013:12). U istom gradu došlo je u aprilu do novog napada na Jevreje, s tim što su vinovnici bili maloletna lica stara oko 11 godina koja su bacala kamenje na njih uz uzvikivanje uvredljivih parola. Upravo nam ovaj podatak ukazuje na veliki stepen indoktrinacije dece i mržnje koja postoji kod njih prema pripadnicima jevrejske zajednice (Antisemitic Incidents Report, 2013:12).

Jevrejska populacija u Velikoj Britaniji je izložena svake godine napadima na svoju imovinu. Ipak, treba napomenuti da u poslednje tri godine dolazi do trenda pada broja izvršenih zločina mržnje prema imovini Jevreja. Tako je i tokom 2013. godine zabeležen pad od $8 \%$ u odnosu na prethodnu godinu. Sa broj- 
kom od 49 imovinskih zločina mržnje 2013. godina ima skoro podjednak broj datih zločina mržnje kao i 2005. godina kada je zabeleženo 40 zločina mržnje prema imovini Jevreja. Od ukupnog broja imovinskih zločina mržnje u 11 slučaja objekat napada su bile sinagoge, dok u jednom slučaju došlo je do oštećenje jevrejskog groblja. U dvadeset slučajeva predmeti oštećenja su bile kuće ili automobili u vlasništvu Jevreja. Za 2013. godinu treba napomenuti da su prvi put bili registrovani imovinski zločini mržnje koji su izvršeni putem hakovanja internet stranica jevrejskih organizacija, uz ostavljanje antisemitskih izjava. Imovinski zločini mržnje ogledaju se u iscrtavanju svastika i pisanju govora mržnje prema Jevrejima na njihovim domovima, drugoj nepokretnoj imovini i automobilima (Antisemitic Incidents Report, 2013:12).

Naredne godine došlo je do naglog skoka broja zabeleženih zločina mržnje prema jevrejskoj populaciji. Naime, sa brojem od 1.168 zabeleženih antisemitskih incidenata 2014. se smatra godinom sa najvećim brojem registrovanih zločina mržnje prema jevrejskoj populaciji. Ujedno, u 2014. godini se prvi put desilo da broj registrovanih zločina mržnje uperenih prema Jevrejima pređe brojku od 1.000. Takođe, broj antisemitskih incidenata u 2014. godini je za $25 \%$ veći nego broj registrovanih zločina mržnje u 2009. koja je prethodno bila sa najvećim brojem zločina mržnje prema jevrejskoj populaciji. Razlog naglog povećanja broja antisemitskih incidenata treba tražiti u novom sukobu u Gazi između Izraelaca i Palestinaca koji je trajao od 8. jula do 26. avgusta 2014. godine. Stoga je došlo do toga da samo u julu tekuće godine bude zabeleženo 314 antisemitskih incidenta, što predstavlja mesec sa najvećim brojem datih dela od kada Community Security Trust prati viktimološki aspet zločina mržnje prema Jevrejima u Velikoj Britaniji. I u sledecem mesecu došlo je do velikog broja registrovanih zločina mržnje. Tako se avgust sa brojkom od 228 antisemitskih incidenata nalazi na trećem mestu u poređenju sa ostalim mesecima u svim godinama. Još jedno interesantno poređenje je komparacija jula i avgusta iz 2014. godine sa julom i avgustom iz 2013. godine. Naime, tokom jula 2013. godine registrovano su 59 incidenata, a tokom avgusta 2013. godine svega 48 antisemitskih incidenata. Drugim rečima, od 8. jula do 26. avgusta 2014. godine registrovan je 501 antisemitski incident, dok je za isti period 2013. godine zabeleženo svega 87 antisemitskih incidenata. Iako je konflikt u Gazi završen tokom avgusta, interesantno je istaći da je u septembru 2014. godine broj antisemitskih incidenata bio 103, što čini dati mesec sa šestim udelom u odnosu na sve druge mesece od kada se meri broj antisemitskih incidenata. Radi poređenja, broj antisemitskih incidenata u 2013. godine za mesec septembar bio je skoro dva puta manji - 59. Moguće je da do povećanog broja antisemitskih incidenata tokom septembra 2014. godine došlo zbog nedavno završenog sukoba u Gazi, ali i zbog veće spremnosti pripadnika jevrejske popu- 
lacije da prijavlju zločine mržnje uperene protiv njih (Antisemitic Incidents Report, 2014:4).

U kategoriji nasilnih zločina mržnje registrovan je 81 incident sa elementima nasilja, što je povećanje od $17 \%$ u odnosu na prethodnu godinu kada je bilo 69 takvih incidenata. Ujedno, 2014. godina je u pogledu nasilnih zločina mržnje imala najveći registrovani broj antisemitskih incidenata još od 2011. godine, kada je zabeleženo 95 zločina mržnje sa elementima nasilja protiv Jevreja. Od ukupnog broja incidenata, njih 63 su posledica situacionog napada na Jevreje na javnim mestima, od čega su 38 žrtava na osnovu svog oblačenja vidljivo bili pripadnici ove populacije. U osam napada su žrtve bili Jevreji koji su se vraćali sa verskih obreda iz sinagoge, dok su kod četiri napada žrtve bile jevrejska deca sa povratka iz školskih klupa. Kod 69 zločina mržnje sa elementima nasilja postoje podaci o žrtvama. Naime, kod 45 nasilnih zločina mržnje žrtve su bile osobe muškog pola, dok su osobe ženskog pola bile žrtve u 11 napada. Kod 13 nasilnih zločina mržnje postojale su grupe sastavljene od oba pola ili parovi koji su bili viktimizirani zbog postojanja predrasuda od strane napadača. Ujedno, Community Security Trust je vodila podatke o godinama starosti žrtava. Tako je kod 44 nasilnih zločina mržnje moguće pronaći ovaj podatak, od čega su kod 29 napada žrtve odrasle osobe, a kod 9 napada su žrtve maloletnici. Kod šest napada žrtve su bile grupe koje čini osobe preko 18 godina života, ali i lica ispod ovog broja u pogledu godina života (Antisemitic Incidents Report, 2014:15).

Postoje određeni zločini mržnje sa elementima nasilja koji su interesantni za predstavljanje. Zločin mržnje sa najtežom posledicom, koji je izvršen tokom 2014. godine, dogodio se januara u Londonu, kada je žrtva prvo nazvana pogrdnim imenom, a zatim udarena vlašom i bejzbol palicom po glavi. Drugi nasilni zločini mržnje nisu izazvali ozbiljnije posledice po žrtve, ali ih treba spomenuti. Mančester je bio poprište novog napada na Jevreje. Naime, u martu je napadnut Jevrejin, dok je vozio bicikl na putu ka sinagogi, na taj način što ga je grupa maloletnika presrela, pri čemu je on pao sa bicikle. Nakon toga maloletnici su ga okružili i počeli da ga udaraju, nanevši mu pri tome lake telesne povrede. Aprila u Londonu je došlo do ulaska dvojice muškaraca u jevrejski restoran uz uzvikivanje nacističkog pozdrava. Jedan od napača uradio je tzv. špansku kragnu gostu restorana. Još jedan interesantan slučaj izvršen je oktobra u Londonu. Dok su petoro jevrejskih devojčica čekale podzemnu železnicu prišao im je čovek govoreći: "Ne biste trebale da budete Jevrejke. Biti Jevrejin je loše", "Vi ćete umreti, ako nastavite da budete pripadnice jevrejske populacije" i "Sve ću vas ubiti posle škole". Zatim je jednu devojku zgrabio za ručni zglob, pozivajući je da krene sa njim kako bi postala hrišćanka, ali mu se ona otrgla i pobegla (Antisemitic Incidents Report, 2014:15-16). 
Tokom 2014. godine izvršen je 81 imovinski zločin mržnje, što je povećanje od $65 \%$ u odnosu na prethodnu godinu, kada su bila registrovana 49 zločina mržnje protiv Jevreja. Ujedno, sa 81 imovinskih zločinom mržnje 2014. je godina sa najvećim brojem zločina mržnje prema imovini Jevreja još od 2010. godine, kada je zabeleženo 83 takvih napada prema imovini u vlasništvu pripadnika jevrejske populacije. Od 81 imovinskog zločina mržnje, njih 39 su bili usmereni prema jevrejskim domovima ili prema automobilima parkiranim ispred njihovih kuća i stanova. Sedam zločina mržnje bilo je usmereno prema jevrejskim grobljima, dok su i tokom 2014. godine bila zabeležena krivična dela hakovanja sajtova jevrejskih organizacija. U Mančesteru je u prvoj polovini godine zabeležen talas crtanja svastika na jevrejskim domovima, ali i grobljima. Kako smo već pomenuli da se u zadnjih par godina javljaju zločini mržnje koji se ogledaju u hakovanju sajtova jevrejskih organizacija, spomenućemo jedan takav slučaj. Jula je došlo do hakovanja internet stranice jevrejske škole iz Londona, pri čemu su ostavljenje sledeće poruke: "Mi smo muslimani”, "Kuran je naša knjiga", "Jerusalim je naš” itd. (Antisemitic Incidents Report, 2014:17).

Godine 2015. zabeležena su 924 antisemitska incidenta, što je pad od 22\% u odnosu na prethodnu godinu koja je bila rekordna u pogledu broja registrovanih zločina mržnje. U poređenju sa drugim godinama treba naglasiti da se 2015. po broju zabeleženih antisemitskih incidenata nalazi na trećem mestu - iza već spomenute 2014. godine, ali i iza 2009. godine kada je izvršen 931 antisemitski incident. Za razliku od 2009. i 2014. godine, kada su postojale spoljne okolnosti u vidu sukoba u Gazi koje su uticale na povećanje broja izvršenih zločina mržnje prema jevrejskoj populaciji, tokom 2015. godine nisu postojale okolnosti u smislu sukoba Palestinaca i Izraelaca u Gazi. Ipak, ne treba zaboraviti spomenuti da su januara i februara 2015. godine izvršeni teroristički napadi na jevrejsku zajednicu u Francuskoj i Danskoj, što je rezultiralo time da data godina ima veliki broj izvršenih zločina mržnje prema Jevrejima. Ujedno, treba naglasiti još jednu specifičnost. Naime, kod 2009. i 2014. godine je nakon završetka sukoba u Gazi došlo do opadanja broja izvršenih zločina mržnje u Velikoj Britaniji, dok kod 2015. godine to nije bio slučaj. Tako su spoljne okolnosti u vidu terorističkih napada dovele do uticaja na vršenje zločina mržnje tokom cele 2015. godine. Najviše su riziku viktimizacije bili izloženi pripadnici jevrejske populacije u Londonu i Mančesteru, jer su tri četvrtine od ukupnog broja antisemitskih incidenata izvršeni u ova dva grada. Razlog treba tražiti u činjenici da najveći broj Jevreja u Velikoj Britaniji živi u Londonu i Mančesteru (Antisemitic Incidents Report, 2015:4).

Od ukupnog broja antisemitskih incidenata njih 86 se kvalifikuju kao zločini mržnje sa elementima nasilja, što je povećanje od $6 \%$ u odnosu na prethodnu godinu. Ujedno, 2015. je godina sa najvećim brojem nasilnih zločina mržnje 
od 2011. godine, kada su zabeležena 95 nasilna zločina mržnje. Takođe, ovo je samo jedan oblik antisemitskih incidenata koji je zabeležio porast tokom 2015 . godine u odnosu na prethodnu godinu kada posmatramo sve druge oblike antisemitskih incidenata (Antisemitic Incidents Report, 2015:5). Od ukupnog broja nasilnih zločina mržnje tokom 2015. godine njih 76 su situacioni napadi na javnim mestima, pri čemu su kod 32 napada žrtve bile, zbog načina oblačenja ili nošenja religijskih obeležja, očigledno Jevreji. Takođe, napadi su bili usmereni prema pripadnicima jevrejske populacije prilikom odlaska u sinagogu - 7 napada. Šest slučajeva su imala za žrtve jevrejsku decu u trenucima kada su se vraćali iz škole. Ujedno, pomenuta nevladina organizacija Community Security Trust uspela je da u sedamdeset pet napada prikupi podatke o polu žrtve. Muškarci se javljaju kao žrtve nasilnih zločina mržnje kod 52 napada, dok se osobe ženskog pola javljaju kao žrtve u 14 napada. Isto tako, kao žrtve se javljaju i grupe koje čine osobe obe pola - u 9 napada. Community Security Trust beleži podatke o starosnoj strukturi žrtava antisemitskih zločina mržnje. Tako je registrovano da kod 25 nasilnih zločina mržnje žrtve su punoletne osobe, dok su maloletnici žrtve u sedamnaest slučajeva. Kod tri napada se kao žrtve javljaju grupe maloletnika i punoletnika (Antisemitic Incidents Report, 2015:15).

Radi sticanja pravog utiska o viktimizaciji pripadnika jevrejske populacije navešćemo par primera o zločinima mržnje sa elementima nasilja izvršenim tokom 2015. godine. Prvi slučaj vredan pažnje dogodio se februara u Londonu, kada je belac iz Istočne Evrope napao ljude u podzemnoj železnici, udarajući ih u lice. Tom prilikom vikao je na ljude, koji su čekali podzemni voz, uz uvredljive poruke prema Jevrejima, kao što su: "Vi, jebeni Jevreji”, "Silazite sa mog voza, vi jebeni Jevreji” itd. Iako žrtve nisu bili isključivo pripadnici jevrejske populacije, policija je ovaj slučaj okarakterisala kao zločin mržnje. Naredni zločin mržnje, koji je rezultirao nanošenjem teških telesnih povreda, izvršen je septembra u Mančesteru. Žrtve su bila četvorica jevrejskih tinejdžera koja su napadnuta od strane trojica belaca na voznoj stanici (Antisemitic Incidents Report, 2015:15). Takođe, izvršeni su nasilni zločini mržnje koji su imali za posledicu lakše telesne povrede. Ponovo je mesto napada bio Mančester, a žrtve su bili trojica jevrejskih 12-ogodišnjaka. Napadači su bili azilanti približno istih godina. Maja 2015. godine u Mančesteru je došlo do još jednog incidenta. Naime, belac je u javnosti pozdravljao prolaznike nacističkim pozdravom. Kada mu je Jevrejin prišao, kako bi protestvovao, bio je udaren, što je za posledicu imalo njegov nokaut (Antisemitic Incidents Report, 2015:15).

Napadi na imovinu u vlasništvu Jevreja imali su tokom 2015. godine pad od $20 \%$ u odnosu na prethodnu godinu. Od ukupno 65 imovinskih zločina mržnje, kod 24 incidenta došlo je do uništenja jevrejskih domova ili vozila parkiranih ispred kuća ili zgrada. U šest slučajeva se radilo o skrnavljenju ili oštećenju 
sinagoga. Takođe, u pet slučajeva je došlo do hakovanja internet sajtova jevrejskih organizacija. Na jevrejskoj školi u Londonu je došlo do ispisivanja grafita "Jevreji napolje", pri čemu je iscrtana i svastika. Do ispisivanja pogrdnih parola dolazilo je i na sinagogama. Tako je na ulaznim vratima jedne londonske sinagoge napisano da su Jevreji ubice. Slučaj, koji treba spomenuti iz razloga zato što je u poslednjih par godina tendencija da se ovakvi zločini mržnje javljaju, jeste hakovanje internet stranica jevrejskih organizacija. Tako je u Londonu tokom marta došlo do hakovanja veb stranice jevrejske organizacije, pri čemu je na prvoj strani napisano da je hakovanje izvršila Islamska država, uz postavljanje njihove zastave (Antisemitic Incidents Report, 2015:17).

U narednoj godini registrovana su 1.309 antisemitskih incidenata, što čini 2016. godinu sa najvećim brojem zločina mržnje izvršenih prema jevrejskoj populaciji u Velikoj Britaniji od kada se oni mere. U odnosi na prethodnu godinu, kada je zabeleženo 960 antisemitskih incidenata, došlo je do povećanja od $36 \%$. Ukoliko bismo analizirali po mesecima broj registrovanih antisemitskih incidenata videćemo da se tokom cele godine beleži ekstremno visok broj izvršenih zločina mržnje. Dovoljno je reći da od maja kada je zabeleženo 135 antisemitskih incidenata do kraja godine svakog meseca bilo registrovano preko 100 zločina mržnje prema jevrejskoj populaciji. Da bismo ukazali na nesvakidašnju okolnost da tokom osam meseci 2016. godine bude izvršavano preko 100 antisemitskih incidenata, navešćemo podatak da je od 2006. godine bilo zabeleženo svega šest meseci sa brojem izvršenih antisemitskih incidenata preko 100 (Antisemitic Incidents Report, 2016:4).

Sa razlogom se postavlja pitanje da li postoji neki događaj koji bi rezultirao time da broj registrovanih antisemitskih incidenata dostigne rekordan nivo 2016. godine. Naime, za razliku od 2009. i 2014. godine, kada su postojali događaji koji su nesumnjivo uticali na povećan broj zločina mržnje prema Jevrejima, tokom 2016. godine nije postojao nijedan takav događaj. S tim u vezi objašnjenje za rekordan broj antisemitskih incidenata treba tražiti u kumulativnom efektu dugoročno postojeće loše atmosfere prema Jevrejima u Velikoj Britaniji. Kao potvrda ovog našeg stava, navešćemo da je od poslednjeg sukoba u Gazi jula i avgusta 2014. godine prosečno beleženo 105 antisemitskih incidenata od datog sukoba do kraja 2016. godine, a u vremenski istom periodu od januara 2012. do juna 2014. godine bilo registrovano mesečno svega 50 antisemitskih incidenata (Antisemitic Incidents Report, 2016:4).

Ukoliko bismo analizirali teritorijalnu rasprostranjenost antisemitskih incidenata uvideli bismo da je preko tri četvrtine od ukupnog broja registrovanih incidenata izvršeno u Londonu i Mančesteru. U odnosu na prethodnu godinu tokom 2016. godine došlo je do povećanja od 65\% - sa 494 antisemitska inciden- 
ta na 813 antisemitska incidenta. Međutim, za razliku od Londona, u Mančesteru je došlo do pada od 9\% - sa 226 antisemitskih incidenata 2015. godine na 205 antisemitskih incidenata naredne godine. Razlika u pogledu broja registrovanih antisemitskih incidenata ostvaren je u poređenju sa drugim gradovima. Tako je 2015. zabeleženo 240 incidenata na 83 različite lokacije, a naredne godine 291 incident na 96 različitih lokacija, što predstavlja povećanje od 21\% (Antisemitic Incidents Report, 2016:4).

Community Security Trust je za 2016. godinu registrovao 107 antisemitskih incidenata sa elementima mržnje. Kako je 2015. godine bilo 83 nasilnih zločina mržnje, zaključujemo da je došlo do povećanja od 29\%. Zabeleženi broj nasilnih krivičnih dela uperenih prema jevrejskoj populaciji je najveći još od 2010. godine, kada je bilo izvršeno 115 takvih incidenata. Situacioni nasilni zločini mržnje izvršeni su u 77 slučajeva, od čega su kod 46 slučajeva žrtve bile Jevreji koji su se zbog svog načina oblačenja jasno razlikovali od ostalih građana. Tri napada su izvršena prema osobama sa povratka iz sinagoge. Ujedno, kod deset incidenata nasilje je bilo usmereno prema deci prilikom vraćanja iz škole. Moguće je saznati polno određenje žrtava nasilnih zločina mržnje. Kod 75 nasilnih zločina žrtve su bile osobe muškog pola, dok su osobe ženskog pola bile žrtve u sedamnaest slučajeva. U sedam napada žrtve su bile i žene i muškarci. Pomenuta nevladina organizacija beležila je i godine starosti žrtava. Tako je kod 32 napada žrtva bila punoletna osoba, a kod 23 napada je bila maloletnik. Kod pet napada žrtve su bile osobe ispod i preko 18 godina starosti (Antisemitic Incidents Report, 2016:16).

$\mathrm{Na}$ kraju analize zločina mržnje sa elementima nasilja za 2016. godinu navešćemo nekoliko interesantnih slučajeva. Jedan od njih vredan pažnje dogodio se januara 2016. godine u Londonu, kada je šest devojaka jevrejskog porekla napadnuto dok se autobusom vraćalo iz škole kući. Napadači su bile dve starije devojke, od kojih je jedan nosila muslimansku odeću. Napadači su uzvikivali: "Vi, jebeni Jevreji, vi, ne biste trebalo da bude ovde. Treba da budete mrtve". Naredni napad, koji je vredan pomena dogodio, se tokom jula u Londonu, kada su trojica jevrejskih dečaka isprebijana, dok su igrali fudbal od strane grupe dečaka afričkog porekla. Napadači su uzvikivali nacistički pozdrav. Tom prilikom jevrejskim dečacima su nanete lake telesne povrede (Antisemitic Incidents Report, 2016:16-17).

Tokom 2016. godine registrovan je 81 imovinski zločin mržnje, što znači da je došlo do povećanja od $25 \%$ u odnosu na 2015. godinu, kada je bilo 65 takvih zločina mržnje. Od ukupnog broja imovinskih zločina mržnje, kod 39 šteta je napravljena na domovima u vlasništvu Jevreja ili na njihovim automobilima parkiranim ispred njihovih kuća i stanova. Kod 11 imovinskih zločina mržnje došlo je do skrnavljenja ili oštećenja sinagoga, dok su jevrejske groblja oštećenja u dva slučaja. Ujedno, došlo je do hakovanja dve internet prezentacije jevrejskih 
organizacija. U Liverpulu je tokom januara bačen kamen na prozor kuće Jevrejina. Napadač je uzvikao uvredljive poruke i pretnje na račun Jevreja. Mančestersko groblje, na kojem se sahranjuju Jevreji, je tokom maja bilo predmet napada (Antisemitic Incidents Report, 2016:18).

Naredna godina, sa registrovana 1.382 antisemitski incidenta, predstavlja godinu sa najvećim brojem zabeleženih zločina mržnje prema Jevrejima ikada. Iako je prethodno 2016. bila godina sa rekordom u pogledu broja zabeleženih zločina mržnje, naredna godina je uspela da je pretekne za 36 antisemitskih incidenata. Ukoliko bismo posmatrali vremensku distribuciju antisemitskih incidenata, videćemo da je više njih bilo zabeleženo u prvih šest meseci 2017. godine nego u drugoj polovini godine. Tako su tokom januara bila registrovana 155 antisemitskih incidenata, što je mesec sa najvećim brojem zločina mržnje prema jevrejskoj populaciji. Naredni mesec sa najvećim brojem incidenata je april, kada je zabeležen 142 antisemitska incidenta. Na trećem mestu se nalazi februar sa 134 registrovana antisemitska incidenta. Novembar, kada je registrovano 89 antisemitskih incidenata, i decembar, kada je zabeleženo 78 antisemitskih incidenata, su meseci sa najmanjim brojem izvršenih zločina mržnje. Ipak, treba naglasiti da su prethodne godine pokazale da se u zadnjim mesecima tokom godine po pravilu beleži najmanji broj antisemitskih incidenata. Ujedno, ističemo da od aprila 2016. do oktobra 2017. godine je trajao niz meseci sa brojem registrovanih antisemitskih incidenata od preko 100 mesečno (Antisemitic Incidents Report, 2017:4).

Objašnjenje za povećan broj registrovanih antisemitskih incidenata treba tražiti u činjenici da je Velika Britanija donela odluku o napuštanju Evropske Unije, te je zbog celokupnog postupka izlaska iz EU, tzv. Brexita, došlo da Radnička partija (Labour Party), sa izrazito antisemitskim stavovima, dobije na značaju. Kriminolozi smatraju da teroristički akti u Vestminsteru, Mančesteru i Londonu nisu direktno uticali na rekordan broj zabeleženih antisemitskih incidenata u Velikoj Britaniji tokom 2017. godine. Naime, Velika Britanija se godinama suočavala sa pretnjama terorista, što je dovelo do toga da vlast podigne stepen bezbednosti u državi. Ujedno, moguće je da je ovo podiglo i svest pripadnika jevrejske zajednice o riziku njihove viktimizacije, te njihove spremnosti da prijavljuju veći broj antisemitskih incidenata kojima su bili izloženi. (Antisemitic Incidents Report, 2017:5).

Utvrđivanje prostornog okvira antisemitskih incidenata je takvo da tri četvrtine njih je izvršeno u Londonu i Mančesteru, kao gradovima sa najvećim jevrejskim zajednicama. London je, za razliku od prethodne godine, imao pad od sedam procenata - 835 incidenata 2016. godine i 773 incidenata 2017. godine. Mančester je imao imao povećanje od 27\%, što znači da je 2017. godine registrovano 261 antisemitski incident, a 2016. godine 206 antisemitskih incidenata. 
Community Security Trust je u svom izveštaju za 2017. godinu naveo da je 348 antisemitskih incidenata izvršeno na osamdeset različitih lokacija širom Velike Britanije, a prethodne godine 305 incidenata na 96 lokacija, što predstavlja povećanje od 14 posto (Antisemitic Incidents Report, 2017:5-6).

Nasilni zločini mržnje su, takođe, bili u porastu u odnosu na 2016. godinu za 34\%. Tako su tokom 2017. godine bila registrovana 145 zločina mržnje sa elementima nasilja. Ovim brojem registrovanih nasilnih zločina mržnje 2017. predstavlja godinu sa najvećim brojem ikada zabeleženih krivičnih dela sa nasiljem uperenim prema Jevrejima. Na ovaj način je čak nadmašen prethodni rekord iz 2009. godine, kada je bilo registrovan 121 napad na jevrejsku populaciju. Od ukupnog broja nasilnih zločina mržnje, njih 85 su bili situacionog karaktera, jer su izvršena na ulicama. Kod 72 napada žrtve su zbog načina odevanja očigledno bili pripadnici jevrejske zajednice. Osam Jevreja je napadnuto prilikom povratka iz sinagoga. Kod 19 napada žrtve su bili jevrejski učenici. Ujedno, Community Security Trust vodi evidenciju o polnom aspektu žrtava nasilnih zločina mržnje. Tako kod 123 napada imamo podatke o polu žrtava. Muškarci su bili žrtve kod 88 napada, dok su osobe ženskog pola to bile u 22 incidenta. Kod trinaest napada žrtve su bile osobe oba pola. Kao i kod prethodnih godina postoji evidencija o godinama starosti žrtava. Kod 55 napada žrtve su bile punoletne osobe. Maloletnici su bili žrtve kod 40 napada, a obe starosne kategorije su bile žrtve u sedam napada (Antisemitic Incidents Report, 2017:18-19).

Iako su se brojni napadi na Jevreje dogodili tokom 2017. godine, mi ćemo kao primer viktimizacije pripadnika jevrejske populacije za datu godinu navesti slučaj iz Londona. Naime, žrtve napada su bili Jevreji, dok su se vraćali autobusom iz škole. Nemilom događaju su prethodila pitanja od strane napadača u smislu da li su oni Jevreji i zašto oni nose te "lude" kapice. Odjednom su jevrejska deca bila izložena udarcima. Iako su pokušali da skrenu pažnju vozaču autobusa kako bi reagovao na napad, on se na to nije obazirao. Jevrejski đaci su izašli iz autobusa na sledećoj stanici, ali su i napadači krenuli za njima. Žrtve su ubrzo ušle u jednu jevrejsku radnju gde je obezbeđenje reagovalo. Jedan napadač je sklopio sporazum o priznanju krivičnog dela. Drugi je osuđen na dvanaestomesečni rehabilitacioni nalog, dok je kod drugih primenjen neki od oblika restorativne pravde (Antisemitic Incidents Report, 2017:19).

Ujedno, jevrejska populacija u Velikoj Britaniji bila je izložena oštećenjima i uništenjima njihove imovine. Tako je tokom 2017. godine došlo do povećanja imovinskih zločina mržnje za $14 \%$ u odnosu na prethodnu godinu. Drugim rečima, došlo je do skoka broja izvršenih imovinskih zločina mržnje sa 81 incidenta na 92 incidenta. Od ukupnog broja zločina mržnje protiv imovine, njih 46 su bili usmereni prema kućama i stanovima u vlaništvu Jevreja, kao i prema nji- 
hovim vozilima parkiranim ispred domova. U 26 slučajeva bila je oštećenja imovina iscrtavanjem svastike ili pogrdnih poruka. Sinagoge su bili oskrnavljenje u devet slučajeva, dok su grobovi preminulih Jevreja oštećeni u tri slučaja. Internet prezentacije jevrejskih organizacija su hakovane tri puta (Antisemitic Incidents Report, 2017:20).

Napadi na jevrejsku imovinu su se ogledali u uništavanju restorana u njihovom vlasništvu. Naime, do ovog uništenja došlo je u Mančesteru tokom juna kada je napadač prvo razbio prozor, a onda ubacio unutra ručno pravljenu bombu. Drugi imovinski zločini mržnje su se odnosili na iscrtavanje svastika ili pogrdnih poruka po zidovima kuća (Antisemitic Incidents Report, 2017:20).

Tokom 2018. godine, prema izveštaju Community Security Trust, izvršeno je 1.652 antisemitska incidenta, što predstavlja rast od 16\% u odnosu na 2017. godinu. Drugim rečima, u 2018. godina predstavlja godinu u kojoj je zabeležen najveći broj ovakvih napada od kada se vodi ovakva evidencija. U odnosu na 2017. godinu zabeležen je rast od 16\%. Ukoliko bismo pratili trend antisemitskih napada od 2014. godine videćemo da u svakoj narednoj godini postoji trend povećanja broja incidenata. Kako su ukupni brojevi antisemitskih napada za 2009. i 2014. godine rezultat reakcije na sukobe u koje je uključen i Izrael, ukupan broj napada za period 2016-2018. godine su stalni obrazac ponašanja, jet u datom periodu nije postojao nijedan veliki eksteran događaj kao okidač napada na pripadnike jevrejske populacije. Ujedno, za vremenski okvir antisemitskih incidenata za 2018. godinu bitno je napomenuti da je prvi put zabeleženo preko 100 napada za svaki mesec tokom godine. Maj predstavlja mesec sa najvećim brojem antisemitskih incidenata - 182. Zatim sledi april sa 151 incidentom, te avgust sa 150 incidenata (Antisemitic Incidents Report, 2018:4).

Analiza kriminogenih faktora na visok nivo antisemitskih incidenata $u$ 2018. godini dovodi nas do zaključka da su to isti činioci koji su uticali na povećan broj incidenata tokom 2016. i 2017. godine. Za 2018. godinu smo već naglasili da nije postojao neki veliki eksterni događaj koji bi uticao na povećanje broja napada, ali dublja analiza vremenskog okvira najvećeg broja napada na pripadnije jevrejske populacije nam ukazuje da su u tim mesecima postojala političke i medijske rasprave optužbi o antisemitizmu među laburistima. Date debate su dovele do toga da pojedinci izvršavaju veći broj napada, pri su čemu istovremeno žrtve bile više ohrabrene da takve napade prijave. Tako je CST zabeležio 148 napada tokom 2018. godine koji su bili posredno ili neposredno vezane oko debata o postojanju navodnog antisemitizma u Laburističkoj stranci. Pored navedenih debata, na povećanja broja napada na Jevreje uticao je sukob ograničenih razmera na granici između Gaze i Izraela u maju kada je ubijano 62 Palestinca od strane izraelske vojske (Antisemitic Incidents Report, 2018:4). 
Analiza prostornog okvira antisemitskih incidenata pokazuje da je skoro tri četvrtine napada zabeleženo u Londonu i Mančesteru. Tako je u Londonu sa 950 napada zabeležen porast od $21 \%$ u odnosu na prethodnu godinu, dok je u Mančestero registrovano smanjenje od 5\% - od 264 indicenta na 250 incidenata. Objašnjenje za postojanje ovakve razlike treba tražiti u postojanju korišćenja drugačijeg jezika i motivacije u ovim gradovima (Antisemitic Incidents Report, 2018:4).

Tokom 2018. godine zabeležen je jedan ekstremni incident, prvi put od 2015. godine. Ovaj ekstremni incident se ogledao u napadu žrtve tokom decembra u Londonu upotrebom noža usled svađe oko prodaje, pri čemu je napadač uzvikivao „Ubiću te, ti jebena Jevrejko”. Međutim, za 2018. godinu u pogledu nasilnih incidenata registrovan je pad od nešto više od 15 procenata (123 nasilna zločina mržnje) u odnosu na 2017. godinu. Največi broj napada na pripadnike jevrejske zajednice su bili nasumični napadi - 101 napad, od kojih je 57 izvršeno jer su se Jevreji vidno razlikovali od drugih po načinu oblačenja. Šest napada je izvršeno u sinagogama ili dok su se Jevreji vraćali sa molitve. U dvadeset slučajeva žrtve napada su bili jevrejski đaci od kojih se pet napada dogodilo u školama, a 15 na putu do ili iz škole. Community Security Trust vodi evidenciju o polu žrtava, te je za 2018. godinu registrovano pol žrtava u 109 napada. U 80 napada su žrtve bili muškarci, dok su žene bile žrtve napada u 21 napadu. U osam napada su žrtve bile osobe oba pola. Pored vođenja evidencije o polu žrtava, Community Security Trust vodi evidenciju o starosti žrtava. Tako je za 2018. godinu zabeleženo da su u 54 incidenta žrtve bile punoletne osobe, a maloletnici su bili žrtve napada u 28 slučajeva. Pet napada su izvršena prema mešovitim grupama. Ujedno, Community Security Trust vodi evidenciju o polu napadača. Naime, kod 82 napada je pomenuta nevladina organizacija imala informaciju o polu izvršioca napada. Od tog broja kod 69 napada izvršioci su osobe muškog pola, dok se žene izvršioci u deset slučajeva. U tri napada su izvršioci osobe različitog pola. Interesantno je spomenuti starost žrtava. S tim u vezi postoji evidencija o godinama starosti žrtava u 87 napada, od čega je u 54 napada žrtva bila punoletna osoba, dok su maloletnici bili viktimizirani u 28 napada. U pet napada su žrtve bile mešovite grupe (Antisemitic Incidents Report, 2018:18-19).

I za 2018. godinu navešćemo neke karakteristične slučajeve u kojim je upotrebljeno nasilje prema pripadnicima jevrejske zajednice. Naime, tokom maja u Londonu došlo je do napada Jevrejina od strane tinejdžera koji je prišao žrtvi, izgovarajući antisemitske komentare. Nakon toga je izvadio upaljač i spalio pramenove žrtvine kose. Još jedan napad vredan pomena dogodio se u Suseku isto tokom maja. Jedanaestogodišnji Jevrejin je verbalno napadan mesecima od strane svojih školskih drugova, pre nego što je fizički napadnut u školskom dvorištu (Antisemitic Incidents Report, 2018:19). 
Oštećenje i uništenje imovine kao oblik zločina mržnje prema pripadnicima jevrejske zajednice je za 2018. godinu imao smanjenje od $16 \%$ u odnosu na prethodnu godinu, što znači da su registrovana 78 incidenata. Ova kategorija zločina mržnje prema Jevrejima je jedina u odnosu na ostale kategorije u kojoj se ukupan broj uništenja i oštećenja imovine za 2018. godinu ne nalazi na prvom ili drugom mestu u poslednjih pet godina. Uvidom u strukturu ove kategorije zločina mržnje vidimo da od ukupnog broja u 33 slučaja su pogođeni domovi ili automobili parkirani ispred domova. U 39 slučajeva došlo je do ispisivanja grafita na imovini Jevreja. Sinagoge su bile meta oštećenja i uništenja imovine u deset slučajeva, dok su jevrejska groblja bila meta u pet slučajeva. Četiri incidenta su se odnosila na podmetanje požara, a jedan na hakovanje sajta jevrejske zajednice (Antisemitic Incidents Report, 2018:20).

\section{Zaključak}

Iako postoje podaci o zločinima mržnje prema Jevrejima, moramo naglasiti da podatke prikuplja i publikuje nevladina organizacija Community Security Trust. Stoga je neophodno da Velika Britanija odredi odgovarajući državni organ u čijoj nadležnosti bi bilo vođenje evidencije o zločinima mržnje, jer bi na taj način Velika Britanija pokazala da ozbiljno shvata fenomen zločina mržnje usmeren prema svojim građanima jevrejskog porekla.

Takođe, Community Security Trust mora da poboljša način vođenja evidencije o antisemitskim incidentima izvršenim putem društvenih mreža, jer način prikupljanja podataka obuhvata samo one incidente koji su prijavljeni ovoj nevladinoj organizaciji, pri čemu prestupnik mora biti iz Velike Britanije, ali i da društveno neprihvatljiv komentar cilja žrtve u Velikoj Britaniji. Zbog ovih ograničenja smatramo da je broj antisemitskih incidenata znatno veći (Antisemitic Incidents Report, 2018:20).

Ujedno, potrebno je raditi na sprovođenju mera prevencije vršenja zločina mržnje prema pripadnicima jevrejskog naroda. Naime, prikupljeni podaci nevladine organizacije Community Security Trust ukazuje na dva bitna zaključka. Prvi zaključak se ogleda u tome da broj zločina mržnje prema Jevrejima raste, te da je stepen njihove viktimizacije iz godine u godinu veći. Drugi zaključak se odnosi na to da Velika Britanija ne sprovodi mere prevencije zločina mržnje prema Jevrejima ili ako ih sprovodi to ne daje rezulate. Stoga je neophodno da se na osnovu prikupljenih podataka pomenute nevladine organizacije napravili akcioni plan prevencije ovog oblika kriminaliteta nasilja, te sprovedu adekvatne mere prevenciju uklanjanjem kriminogenih faktora koji dovode do njegovog vršenja, 
kao i merama usmerenih ka otklanjanju viktimogenih predispozicija koje postoje kod pripadnika jevrejske zajednice.

\section{Literatura}

- Perry, B. (2009) Hate crimes. London: Greenwood Publishing Group.

- Rawcliffe, C., Wilson, R. (2006) Medieval Norwich. London: A\&C Black

\section{Internet izvori}

- Antisemitic Incidents Report. (2010) London: Community Security Trust, London, dostupno na: https://cst.org.uk/data/file/b/4/Incidents-Report-2010.1425052704.pdf, stranici pristupljeno 18. marta 2018. godine;

- Antisemitic Incidents Report (2011) London: Community Security Trust, London, dostupno na: https://cst.org.uk/data/file/d/b/Incidents-Report-2011.1425052805.pdf, stranici pristupljeno 19. marta 2018. godine;

- Antisemitic Incidents Report (2012) London: Community Security Trust, London, dostupno na: https://cst.org.uk/data/file/d/c/Incidents-Report-2012.1425052902.pdf, stranici pristupljeno 19. marta 2018. godine;

- Antisemitic Incidents Report (2013) London: Community Security Trust, London, dostupno na: https://cst.org.uk/data/file/5/c/Incidents-Report-2013.1425053045.pdf, stranici pristupljeno 19. marta 2018. godine;

- Antisemitic Incidents Report (2014) London: Community Security Trust, London, dostupno na: https://cst.org.uk/data/file/5/5/Incidents-Report-2014.1425053165.pdf, stranici pristupljeno 24. marta 2018. godine;

- Antisemitic Incidents Report (2015) London: Community Security Trust, London, dostupno na: https://cst.org.uk/data/file/1/9/Incidents_Report_2015.1454417905.pdf, stranici pristupljeno 24. marta 2018. godine;

- Antisemitic Incidents Report (2016) London: Community Security Trust, London, dostupno na: https://cst.org.uk/data/file/b/e/Incidents\%20Report\%20 2016.1486376547.pdf, stranici pristupljeno 29. marta 2018. godine;

- Antisemitic Incidents Report (2017) London: Community Security Trust, London, dostupno na: https://cst.org.uk/data/file/a/b/IR17.1517308734.pdf, stranici pristupljeno 23. januara 2020. godine;

- Antisemitic Incidents Report (2019) London: Community Security Trust, London, dostupno na: https://cst.org.uk/public/data/file/2/9/Incidents\%20Report $\% 202018 \% 20-\% 20$ web.pdf, stranici pristupljeno 1. aprila 2018. godine; 
- http://www.jewishvirtuallibrary.org/global-anti-semitic-trends-report-2001, stranici pristupljeno 12. marta 2018. godine;

- https://www.worldjewishcongress.org/en/about/communities/GB\%20 $\% \mathrm{C} 2 \% \mathrm{~A} 0$, stranici pristupljeno 22. januara 2020. godine.

Darko DIMOVSKI, PhD

Faculty of Law, University of Niš

\section{JEWS AS VICTIMS OF HATE CRIME IN GREAT BRITAIN}

There are many examples of prejudices existing against members of the Jewish people throughout history. The author therefore cited a number of examples in the introductory section to illustrate the negative attitudes of the majority population towards this ethnic community. Considering that the place where the Jewish community is among the most numerous in the world, is the UK, the author further elaborates on the extent and structure of hate crimes against Jews by years, trying to explain the dynamics of hate crimes committed. In the end of the paper author points to the conclusions that could be applied to reduce the victimization of members of the Jewish community.

Key words: hate crime, Jews, Great Britain, victims 